\title{
A new perspective on cholesterol in pediatric health: association of vitamin D metabolism, respiratory diseases, and mental health problems
}

Jeana Hong, MD, PhD

Department of Pediatrics, Kangwon National University School of Medicine, Chuncheon, Korea

Cholesterol, the main structural molecule of cell membranes, is involved in essential functions of the human body. Dyslipidemia is an established risk factor for cardiovascular diseases (CVDs) that is observed even in childhood. To reduce the risk of CVDs in children, several clinical guidelines have been published for the management of pediatric dyslipidemia. However, pediatric dyslipidemia is also associated with several health problems other than CVDs. This article reviews the current data on dyslipidemia-related pediatric health issues. There is strong evidence that low serum vitamin D levels, asthma, and mental health problems may be associated with dyslipidemia in the pediatric population regardless of body mass index. This review also highlights the need for further large-scale population-based studies in the Korean pediatric population to establish effective strategies for promoting children's health.

Key words: Lipid, Cholesterol, Vitamin D, Asthma, Mental health

\section{Key message}

- Pediatric dyslipidemia is associated with several health problems besides cardiovascular diseases.

- There is a direct association between pediatric dyslipidemia and low serum vitamin D levels, asthma, and mental health problems regardless of body mass index.

More large-scale nationally representative studies are needed to establish the appropriate cutoff points for the definition of dyslipidemia that is a prerequisite for further epidemiological studies in the Korean pediatric population.

\section{Introduction}

Cholesterol is a major structural constituent of the cell membrane and an essential molecule for the synthesis of steroid hormones, bile acids, and fat-soluble vitamins in the body. Plasma cholesterol, absorbed from dietary sources with triglycerides
(TG) or synthesized in the liver, is transported by lipoproteins such as chylomicrons, very-low-density lipoprotein, lowdensity lipoprotein (LDL), and high-density lipoprotein (HDL). Dyslipidemia is defined as abnormal plasma levels of cholesterol, TG, or lipoproteins.

In adults, dyslipidemia is an established risk factor for cardiovascular diseases (CVDs) along with diabetes, hypertension, and obesity. ${ }^{1)}$ Increasing evidence shows that pediatric dyslipidemia is even associated with the development of atherosclerosis and premature CVDs in early childhood.,3) Thus, several expert committees have developed clinical guidelines for the management of childhood dyslipidemia to promote cardiovascular health in the pediatric population. ${ }^{3-5)}$

Dyslipidemia is associated with several other health problems in children. In practice, childhood dyslipidemia tends to be considered only as a complication of childhood obesity. This article reviews the current data on dyslipidemia-related pediatric health issues other than CVDs to broaden our understanding of cholesterol in childhood.

\section{Definition of dyslipidemia in Korean children and adolescents}

To define dyslipidemia in children and adolescents, the normal distribution of lipids and lipoproteins in the pediatric population must first be determined. Because lipid levels change with growth and maturation, the normal values in children differ from those in adults and vary further by age, sex, and ethnicity. ${ }^{6}$ In the United States, the normal lipid and lipoprotein levels in childhood, adolescence, and adulthood were established based on multiple screening cohort studies. ${ }^{3)}$ In 1992, an expert panel of the National Cholesterol Education Program (NCEP) on cholesterol levels in children suggested the cutoff points to delineate total cholesterol (TC) and LDL cholesterol (LDL-C) levels and categorized them as "acceptable," "borderline," and "high."7) In 2011, the expert committee of the National

Corresponding author: Jeana Hong, MD, Department of Pediatrics, Kangwon National University Hospital, 156 Bangyeong-ro, Chuncheon, Gangwon 24289, Korea 


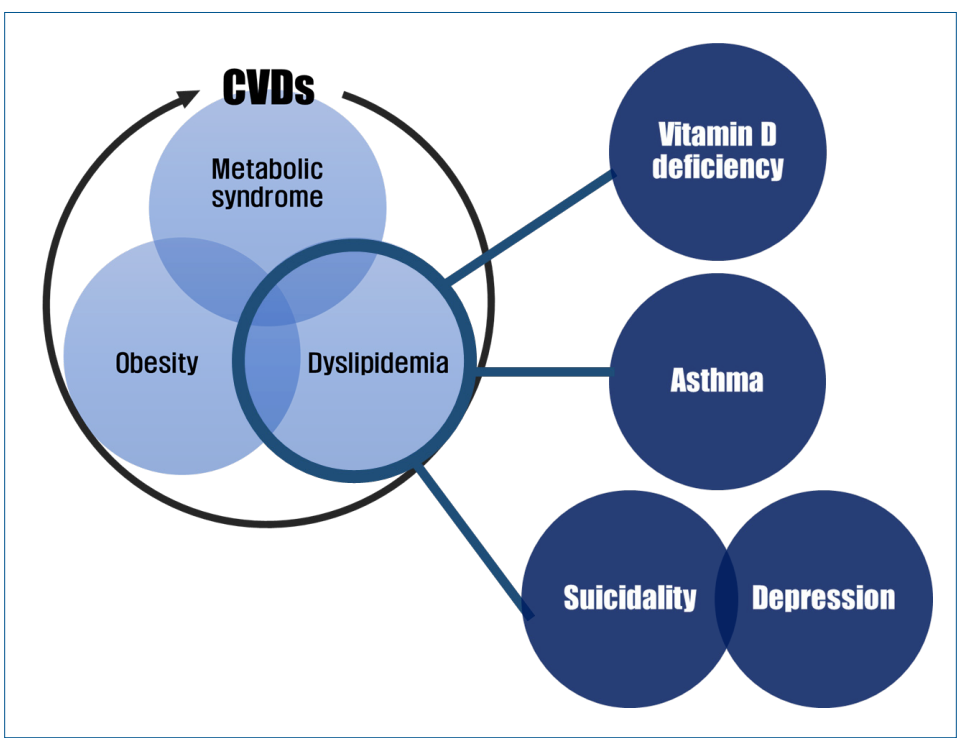

Graphical abstract. CVDs, cardiovascular diseases.

Heart, Lung and Blood Institute (NHLBI) updated the NCEP pediatric guidelines and defined the TC, LDL-C, TG, and HDL-cholesterol (HDL-C) levels at which further intervention should be considered to reduce the risk of CVDs. ${ }^{3)}$ Thereafter, several academic societies including the American Academy of Pediatrics, American Heart Association, and American College of Cardiology adopted the NHLBI definition for their updated guidelines for the management of pediatric dyslipidemia. ${ }^{3-5)}$ The Korean Society of Pediatric Endocrinology recently established clinical practice guidelines in which the 2011 NHLBI guidelines were also adopted for determining the levels of screening and treatment for pediatric dyslipidemia. ${ }^{8)}$ In the population of Korean children and adolescents, dyslipidemia is defined as one of the following: serum TC level, $\geq 200 \mathrm{mg} / \mathrm{dL}$; LDL-C, $\geq 130$ $\mathrm{mg} / \mathrm{dL}$; non-HDL, $\geq 145 \mathrm{mg} / \mathrm{dL}$; TG $\geq 130 \mathrm{mg} / \mathrm{dL}$ (in children $0-9$ years of age, $\geq 100 \mathrm{mg} / \mathrm{dL}$ ); and HDL-C, $<40 \mathrm{mg} / \mathrm{dL}$.

As shown in Table 1, the suggested cutoff points for "borderline" and "abnormal" levels represented the 75th and 95th percentiles, respectively, while the low cutoff point for "abnormal" HDL-C represented the 10th percentile. However, according to recent reports based on data from the Korean National Health and
Nutrition Examination Surveys (KNHANES, 2007-2013, 2019) of Korean individuals aged 10-19 years, the percentile value of the cutoff points for "abnormal" levels differs from that suggested in the guidelines. ${ }^{9-11)}$ For example, the cutoffs of a TC level of 200 $\mathrm{mg} / \mathrm{dL}$ and non-HDL-C of $145 \mathrm{mg} / \mathrm{dL}$ are equivalent to the $90 \mathrm{th}-$ 95th percentiles, while the cutoff of HDL-C of $40 \mathrm{mg} / \mathrm{dL}$ falls to the 10th-25th percentile among Korean children (Table 1). In addition, a TG cutoff of $130 \mathrm{mg} / \mathrm{dL}$ corresponds to the 75 th90th percentile; hence, some reports have suggested a cutoff of $150 \mathrm{mg} / \mathrm{dL}$ for TG, which corresponds to the 90th percentile for Korean children, as the "abnormal" cutoff in Korean children and adolescents. ${ }^{12,13)}$

Therefore, additional large-scale nationally representative studies are needed to define the appropriate cutoff points for the Korean pediatric population. Additionally, there are no reports on the normal distribution of lipid profiles in Korean children under 10 years of age. Definitive criteria for dyslipidemia in the Korean pediatric population should first be determined to establish effective screening or treatment guidelines for dyslipidemia in Korean children and adolescents.

Table 1. Definition of childhood dyslipidemia

\begin{tabular}{|c|c|c|c|c|c|}
\hline \multirow{2}{*}{ Unit (mg/dL) } & \multirow{2}{*}{ Acceptable } & \multirow{2}{*}{ Borderline } & \multirow{2}{*}{ Abnormal* } & \multicolumn{2}{|c|}{ The cutoffs of the 95th percentile in Korean pediatric data } \\
\hline & & & & KNHANES $(2007-2013)^{9,10)}$ & KNHANES (2019) ${ }^{11)}$ \\
\hline Total cholesterol & $<170$ & 170-199 & $\geq 200$ & 203 & 210 (boys), 213 (girls) \\
\hline LDL-C & $<110$ & $110-129$ & $\geq 130$ & 129 & \\
\hline Non-HDL-C & $<120$ & $120-144$ & $\geq 145$ & 140-156 (boys), 149-158 (girls) & \\
\hline \multicolumn{6}{|l|}{ Triglyceride } \\
\hline $0-9 y r$ & $<75$ & $75-99$ & $\geq 100$ & & \\
\hline $10-19 y r$ & $<90$ & $90-129$ & $\geq 130$ & 185 & 188 (boys), 167 (girls) \\
\hline HDL-C & $>45$ & $40-45$ & $<40$ & $38^{*}$ & \\
\hline
\end{tabular}

KNHANES, Korean National Health and Nutrition Examination Surveys (year surveys performed); LDL-C, low-density lipoprotein cholesterol; HDL-C, highdensity lipoprotein cholesterol

*The levels correspond to the 95th percentile for total cholesterol, LDL-C, non-HDL-C, and triglyceride and the 10th percentile for HDL-C. 


\section{Prevalence of dyslipidemia in Korean children and adolescents}

According to a nationwide cross-sectional survey of the KNHANES, the prevalence of hypercholesterolemia in Korean adults aged 30 years or older has almost doubled over 10 years from $10.8 \%$ and $11.8 \%$ in men and women in 2009 to $21.0 \%$ and $23.1 \%$, respectively, in 2019.11) The prevalence of hypercholesterolemia varied by sex and age in Korean adults. The prevalence of hypercholesterolemia in men is relatively high before the age of 60 years and higher in women aged over 60 years. ${ }^{14)}$

Meanwhile, the prevalence or incidence of dyslipidemia in Korean children and adolescents is unknown due to the lack of nationwide statistics. Based on a study of Korean children aged 10-18 years using data from the KNHANES IV (2007-2009), $19.7 \%$ of children had at least one abnormal lipid profile.") The prevalence of hypercholesterolemia, a high LDL-C, a high TG, and a low HDL-C was reportedly $6.5 \%, 4.7 \%, 10.1$ $\%$, and $7.1 \%$, respectively. Girls were more likely to have hypercholesterolemia and higher LDL-C levels than boys ( $7.4 \%$ vs. $5.8 \%$ for TC; $5.5 \%$ vs. $4.1 \%$ for LDL-C). However, the cutoff points applied in the study for a high TG $(\geq 150 \mathrm{mg} /$ $\mathrm{dL})$ and low HDL-C $(<35 \mathrm{mg} / \mathrm{dL})$ differed from the currently adopted definition of pediatric dyslipidemia. When the cutoffs for the low HDL-C of $<40 \mathrm{mg} / \mathrm{dL}$ were applied, the prevalence of low HDL-C changed from $7.1 \%$ to $11.9 \%{ }^{8}{ }^{8}$

To understand the sex- and age-specific trends in the prevalence of dyslipidemia in Korean children and adolescents, further large-scale studies that include nationwide statistics are required. Most importantly, the determination of the definitive criteria for dyslipidemia among the Korean pediatric population is a prerequisite for epidemiological studies.

\section{Etiology of dyslipidemia in children and adolescents}

\section{Primary dyslipidemia}

Primary dyslipidemia is caused by genetic defects (i.e., monogenetic and polygenic) in lipoprotein metabolism. Patients with inherited disorders of dyslipidemia often have a family history of premature CVDs with mostly autosomal dominant penetration. Monogenic conditions include familial hypercholesterolemia (FH), familial defective apolipoprotein $\mathrm{B}$, familial dysbetalipoproteinemia, and familial hypertriglyceridemia. In adults, $\mathrm{FH}$ is the most common single-gene mutation disease associated with CVDs. ${ }^{15)}$ A polygenic condition is caused by an interaction between multiple susceptibility genes and the environment. This includes familial combined hyperlipidemia (FCHL) and polygenic hypercholesterolemia, with FCHL being the most common primary lipid disorder, occurring in $1 \%-2 \%$ of the population. The phenotypes of FCHL overlap those of metabolic syndrome and diabetic dyslipidemia; in children with
FCHL, they most often manifest with obesity such that their dyslipidemia is often considered associated with obesity. ${ }^{15)}$

\section{Secondary dyslipidemia}

Secondary dyslipidemia is defined as dyslipidemia caused by diseases and certain conditions, including obesity, type 2 diabetes mellitus, nephrotic syndrome, chronic inflammatory disease, hypothyroidism, hepatic disease, and the use of certain drugs (e.g., corticosteroids, isotretinoin, $\beta$-blocking agents, chemotherapeutic agents, antiretroviral agents, and psychotropic medications such as olanzapine). ${ }^{3,15)}$ The excessive dietary intake of saturated fats is also an important cause of dyslipidemia.

Etiological studies of pediatric dyslipidemia are rare, and most cases of pediatric dyslipidemia are considered secondary dyslipidemia. In particular, obese children with dyslipidemia show a pattern of combined dyslipidemia presenting as a mild elevation in TC and LDL-C or a moderate to severe elevation in TG and a low HDL-C. ${ }^{3)}$ However, primary dyslipidemia should be considered a differential diagnosis, even in children with obesity or diabetes when there is a family history of dyslipidemia or premature CVD.

\section{Pediatric health issues associated with lipid profiles}

\section{Vitamin D metabolism associated with dyslipidemia}

Vitamin D is an essential component of calcium metabolism and bone health. In addition to its classical physiological function, vitamin $\mathrm{D}$ is involved in immune function, anti-inflammatory activities, and endocrine function. ${ }^{16,17)}$ Several mechanisms have been suggested to explain how vitamin D can affect lipid profiles. Vitamin D reportedly stimulates calcium absorption in the intestine, and increased levels of intestinal calcium inhibit the synthesis and secretion of hepatic TG and reduce the intestinal absorption of fatty acids. ${ }^{18,19)}$ The absorbed calcium then induces the conversion of cholesterol into bile acid, thereby decreasing cholesterol levels. ${ }^{20)}$ Vitamin D can influence TG concentrations by interacting with parathyroid hormone (PTH). High serum levels of 25 -hydroxy vitamin D (25[OH]D) suppress serum PTH levels, which in turn increase TG levels. ${ }^{21)}$ Vitamin D deficiency may also cause insulin resistance by impairing the function of pancreatic $\beta$-cells that could affect lipoprotein metabolism, leading to increased TG and decreased HDL-C levels. ${ }^{22)}$

It is well documented that vitamin D is associated with cardiometabolic risk factors such as obesity, high blood pressure, metabolic syndrome, and CVDs. ${ }^{23,24)}$ However, in a recent crosssectional study of 3,788 Chinese adults, vitamin D deficiency was directly associated with dyslipidemia regardless of obesity, diabetes, and hypertension status. ${ }^{25)}$ The study indicated that serum 25(OH)D levels were inversely correlated with LDL-C and TG levels and positively correlated with HDL-C levels, even after the adjustment for several other cardiometabolic risk factors. In the pediatric population, a meta-analysis of 17 cross- 
sectional pediatric studies of 25,394 subjects revealed a weak significant association between vitamin $\mathrm{D}$ status and TC, TG, LDL-C, and HDL-C levels, indicating that higher serum levels of vitamin $\mathrm{D}$ are associated with a more favorable lipid profile in children and adolescents. ${ }^{26)}$

On the other hand, a few Korean studies of the pediatric population yielded inconsistent findings for each lipid profile. A cross-sectional study of 310 Korean children aged 10-12 years reported a significant association between serum vitamin D levels and metabolic risk factors such as dyslipidemia and insulin resistance. ${ }^{27)}$ However, after the adjustment for body fat, sex, and age, serum 25(OH)D levels were inversely correlated with TC and TG levels but not with HDL-C levels. Another study of 1,660 Korean children aged 9 years found that low levels of vitamin $\mathrm{D}$ (serum 25[OH]D $<15.5 \mathrm{ng} / \mathrm{mL}$ ) were associated with hypertriglyceridemia but not with low HDL-C, the components of metabolic syndrome, even after the adjustment for body mass index (BMI). ${ }^{28)}$ Additionally, data from a nationally representative sample of 1,540 Korean adolescents revealed no significant relationship between vitamin D insufficiency (serum $25[\mathrm{OH}] \mathrm{D} \leq 20 \mathrm{ng} / \mathrm{mL}$ ) and hypertriglyceridemia or low HDL-C with or without the adjustment for confounding variables such as BMI and sex. ${ }^{29)}$ In a recent study of nonobese children aged 9-18 years, vitamin D levels were significantly inversely associated with TG levels and TG/HDL-C ratios. The vitamin D-deficient group (serum 25[OH]D $<20 \mathrm{ng} / \mathrm{mL}$ ) showed higher serum TG levels and TG/HDL-C ratio than the normal vitamin D level group. ${ }^{30)}$ Another recent study of nationwide representative data of 2,581 nonobese children aged 12-18 years revealed that vitamin D deficiency (serum $25[\mathrm{OH}] \mathrm{D} \leq 20$ $\mathrm{ng} / \mathrm{mL}$ ) was associated with low HDL-C levels but not with high TC, TG, and LDL-C levels. ${ }^{31)}$

Despite the inconsistent results for each lipid profile, most studies showed an overall positive association between serum $25(\mathrm{OH}) \mathrm{D}$ levels and favorable lipid profiles. However, it is unclear whether vitamin D supplementation positively affects lipid profiles. ${ }^{32,33)}$ Some clinical trials of Iranian adolescents showed inconsistent results regarding the effects of vitamin D on lipid profiles. ${ }^{34,35)}$ In a recent randomized single-blind placebocontrolled trial of Iranian boys, the monthly supplementation of vitamin D (50,000 IU) for 6 months decreased serum TG levels and increased HDL levels. ${ }^{36}$ Meanwhile, a recent metaanalysis of randomized controlled trials showed that vitamin D supplementation increased LDL-C levels without affecting TC, HDL-C, and TG levels, highlighting the unfavorable effects of vitamin $\mathrm{D}$ supplementation on LDL-C. ${ }^{37)}$

In practice, obese patients with dyslipidemia tend to focus more on vitamin D replacement to improve their lipid profiles. However, adipose tissue may serve as the site of sequestration of the fat-soluble vitamin $\mathrm{D}$, trapping it and lowering its serum levels. Therefore, instead of lifestyle modifications such as weight reduction, exercise, or diet change to reduce fat tissue, clinicians should be cautious of using vitamin D supplementation when dealing with obese children. Large well-designed population- based interventional studies are required by controlling for confounders that involve lifestyle variables such as dietary factors or physical activities to determine the relationship between vitamin D replacement and lipid profile improvement.

\section{Respiratory diseases associated with dyslipidemia}

Cholesterol has a complex effect on inflammation at the cellular level causing a proinflammatory cellular response. ${ }^{38)}$ The dysregulation of cholesterol and phospholipid transport in airway smooth muscle cells may be important in the pathogenesis of asthma. ${ }^{39)}$ The metabolic abnormalities of dyslipidemia or hyperinsulinemia may activate the innate and adaptive immunities that amplify the propagation of inflammation in the respiratory tract and subsequently increase bronchomotor tone, airway inflammation, and hyperreactivity. ${ }^{40)}$

Several reports have detailed the positive association between obesity and asthma in children. ${ }^{41,42)}$ Overweight or obesity are well-known significant risk factors for childhood asthma and wheezing. In the obesity-asthma link, diverse mechanisms have been suggested in which metabolic abnormalities such as dyslipidemia or insulin resistance have been considered possible contributing factors for the development of "obese asthma." In other words, obesity is closely linked with the development of dyslipidemia, insulin resistance, or diabetes, which in turn compromises respiratory function. ${ }^{44)}$

On the other hand, there is strong evidence that asthma is directly associated with dyslipidemia regardless of BMI. ${ }^{43,45)}$ In a study of 17,994 children aged 4-12 years, physician-diagnosed asthma was significantly associated with high serum TG levels after control for BMI and sex. ${ }^{45)}$ In a cross-sectional study of 85,555 Spanish adults, self-reported wheezing was associated with high serum TG and low HDL-C levels after adjustment for adiposity, suggesting TG and HDL-C as markers or inducers of inflammation-associated disease. ${ }^{46)}$ However, a meta-analysis of 20 studies including 9 pediatric reports revealed that asthma was associated with higher TC and LDL-C levels but not with TG and HDL-C levels. ${ }^{47)}$ In particular, accumulating evidence suggests an association of HDL-C with pulmonary function. ${ }^{48)}$ Another recent meta-analysis of pediatric studies showed that children with asthma had lower HDL levels, but no association with LDL-C levels was noted. ${ }^{49}$ A recent nationwide population-based study of Korean adolescents using KNHANES V (2010-2012) data reported that the asthma prevalence was higher among adolescents with high TC levels and an elevated TG/HDL-C ratio, and the correlation was maintained even after the adjustment for confounding factors such as BMI and energy and fat intakes. ${ }^{50)}$ However, the opposite findings were observed in a study of healthy Korean male adolescents, including an association between high HDL-C level and reduced pulmonary function..$^{51)}$

Despite the conflicting results for each lipid profile among previous reports, it has to be noted that several studies reported no association between respiratory function and dyslipidemia. A recent study of nationwide representative survey data of 23,841 
children in the United States reported no association between the current presence of childhood asthma and serum lipid profiles after the control for confounders such as sex, race, and BMI $\mathrm{z}$ score. ${ }^{52)}$ In addition, a recent cohort study revealed that lipid levels at 6 years of age were not associated with respiratory function and physician-diagnosed asthma at 10 years of age. ${ }^{53)}$

To determine the relationship between respiratory inflam. mation and lipid profiles, further research is needed on other inflammatory respiratory tract diseases including asthma by controlling for confounders such as dietary intake, glucose metabolism, systemic infection, and body adiposity, which may affect the lipid profile and respiratory inflammation.

\section{Mental and behavioral health problems associated with dyslipidemia}

Increasing evidence supports the association between mental health problems and serum lipid levels over the past decades. ${ }^{54)}$ Cholesterol is essential to axonal functioning and myelin formation in the central nervous system. ${ }^{55)}$ Low cholesterol level-induced alteration of microviscosity in the lipid bilayer of the cell membrane causing serotonin transmission dysfunction or serotoninergic receptor alteration has been partly implicated in the pathophysiology of psychiatric illnesses such as suicidality and mood alteration. ${ }^{56-58)}$

Several observational studies have reported on the association between lipid profiles and depression, depressive mood, and suicidality, including suicide attempts, ideation, and completion, but their results are inconsistent. A meta-analysis of 65 epidemiological studies reported an inverse association between suicidality and serum lipid levels, indicating that patients with suicidal ideation had significantly lower serum lipid levels. ${ }^{59)}$ Another meta-analysis of 36 articles published through 2015 demonstrated a significant association between depression and low serum LDL levels. ${ }^{60)}$ In contrast, a recent meta-analysis concluded that the first episode of major depressive disorder in adults was significantly associated with elevated TG levels and decreased HDL levels but was not associated with TC and LDL-Clevels. ${ }^{61)}$

According to Korean data, the association between lipid profiles and mental health problems may differ by age and sex. A recent nationwide representative study using KNHANES VI-2 (2014) data reported significantly higher HDL-C levels in men with depression and higher TG levels in women with suicidal ideation after the adjustment for covariates such as age, medical illness, daily intake, and vitamin D level. ${ }^{62)}$ Another nationally representative study of KNHANES V (2010-2012) data revealed that suicidal ideation was associated with lower TG levels in Korean men aged over 65 years. ${ }^{63)}$

Only a few studies have investigated the association between serum lipid levels and mental or behavioral health problems in children and adolescents. ${ }^{64,65)}$ Furthermore, most studies in Western countries focused on inpatient samples reported inconsistent results. In the case of the Korean pediatric population, a recent nationwide population-based study of KNHANES (2013-2016) data found that boys with depressive mood have higher LDL levels as categorical measurements after the adjustment for age, daily intake, and household income. ${ }^{66}$ In a prospective cohort study of healthy Korean adolescents with

Table 2. Summary of studies on vitamin D metabolism related to childhood dyslipidemia

\begin{tabular}{|c|c|c|c|c|c|}
\hline Health problems & Study & Study design & $\begin{array}{l}\text { Subjects } \\
\text { number }\end{array}$ & $\begin{array}{l}\text { Subjects } \\
\text { characteristics }\end{array}$ & Results \\
\hline Serum 25(OH)D levels & Ha et al., ${ }^{27)} 2012$ & Cross-sectional $^{\text {a) }}$ & 310 & $\begin{array}{l}\text { Koreans aged } 10-12 \\
\text { years }\end{array}$ & $\begin{array}{l}\text { Inverse association with TC and TG levels } \\
\text { No association with HDL-C levels }\end{array}$ \\
\hline $\begin{array}{l}\text { Low vitamin D } \\
\text { (serum } 25[\mathrm{OH}] \mathrm{D}<15.5 \mathrm{ng} / \mathrm{mL} \text { ) }\end{array}$ & Lee et al., ${ }^{28)} 2013$ & Cross-sectionala $^{\mathrm{a}}$ & 1,660 & Koreans aged 9 years & $\begin{array}{l}\text { Association with high TG } \\
\text { No association with low HDL-C }\end{array}$ \\
\hline $\begin{array}{l}\text { Vitamin D insufficiency } \\
\text { (serum 25[OH]D } \leq 20 \mathrm{ng} / \mathrm{mL} \text { ) }\end{array}$ & Nam et al.,. 2014 & Cross-sectionala $^{\mathrm{a}}$ & 1,540 & $\begin{array}{l}\text { Koreans aged 12-18 } \\
\text { years }\end{array}$ & No association with high $\mathrm{TG}$ and low HDL-C \\
\hline Serum 25(OH)D levels & Kim and Jeong ${ }^{30)} 2019$ & Cross-sectional & 243 & $\begin{array}{l}\text { Nonobese Koreans } \\
\text { aged } 9-18 \text { years }\end{array}$ & $\begin{array}{l}\text { Inverse association with TG levels and TG/ } \\
\mathrm{HDL}-\mathrm{C} \text { ratio }\end{array}$ \\
\hline $\begin{array}{l}\text { Vitamin D deficiency } \\
\text { (serum } 25[\mathrm{OH}] \mathrm{D} \leq 20 \mathrm{ng} / \mathrm{mL} \text { ) }\end{array}$ & Song et al., ${ }^{31)} 2020$ & Cross-sectional & 2,581 & $\begin{array}{l}\text { Nonobese Koreans } \\
\text { aged } 12-18 \text { years }\end{array}$ & $\begin{array}{l}\text { Association with low HDL-C } \\
\text { No association with high TC, high TG, and } \\
\text { high LDL-C }\end{array}$ \\
\hline $\begin{array}{l}\text { Vitamin D supplementation } \\
(1,000 \mathrm{IU}) \text { daily }\end{array}$ & Tavakoli et al., ${ }^{34)} 2016$ & RCT & $\begin{array}{l}20 \text { Trial } \\
20 \text { Placebo }\end{array}$ & $\begin{array}{l}\text { Healthy Iranians aged } \\
10-14 \text { years }\end{array}$ & Increased HDL-C levels \\
\hline $\begin{array}{l}\text { Vitamin D supplementation } \\
(50,000 \mathrm{IU}) \text { weekly }\end{array}$ & $\begin{array}{l}\text { Khayyatzadeh et al., } \\
2018\end{array}$ & $\begin{array}{l}\text { Prospective } \\
\text { interventional }\end{array}$ & 940 & $\begin{array}{l}\text { Iranian girls aged } \\
12-18 \text { years }\end{array}$ & $\begin{array}{l}\text { Decreased TC and LDL-C levels } \\
\text { No effect on HDL-C levels }\end{array}$ \\
\hline $\begin{array}{l}\text { Vitamin D supplementation } \\
(50,000 \mathrm{IU}) \text { monthly }\end{array}$ & $\begin{array}{l}\text { Yarparvar et al., } \\
2020\end{array}$ & $\mathrm{RCT}$ & $\begin{array}{l}34 \text { Trial } \\
37 \text { Placebo }\end{array}$ & $\begin{array}{l}\text { Healthy Iranian } \\
\text { boys aged } 17 \\
\text { years }\end{array}$ & $\begin{array}{l}\text { Decreased TG levels and increased } \\
\text { HDL-C levels }\end{array}$ \\
\hline Serum 25(OH)D levels & $\begin{array}{l}\text { Kelishadi et al., }{ }^{26)} \\
2014\end{array}$ & Meta-analysis & 25,394 & $\begin{array}{l}17 \text { cross-sectional } \\
\text { pediatric studies }\end{array}$ & $\begin{array}{l}\text { Weak inverse association with TC, TG, } \\
\text { and LDL-C levels, and direct associa- } \\
\text { tion with HDL-C levels }\end{array}$ \\
\hline Vitamin D supplementation & Hauger et al., ${ }^{37)} 2020$ & Meta-analysis & 1,088 & $\begin{array}{l}14 \mathrm{RCT} \text { pediatric } \\
\text { studies }\end{array}$ & $\begin{array}{l}\text { Increased LDL-C levels } \\
\text { No effects on TC, HDL-C, and TG levels }\end{array}$ \\
\hline
\end{tabular}

25(OH)D, 25-hydroxy vitamin D; TC, total cholesterol; TG, triglyceride; HDL-C, high-density lipoprotein cholesterol; LDL-C, low-density lipoprotein cholesterol; $\mathrm{RCT}$, randomized controlled trial.

a) The results were analyzed after adjusting for body fatness/body mass index and/or sex. 
an average follow-up of 6 years, consistently low or increased TC levels during adolescence increased the risk of depressive symptoms in men during early adulthood. ${ }^{67)}$ These findings indicate the different strategies to prevent depression by managing the lipid profile during adolescence. Interestingly, a recent community-based study of Korean children aged 10-12 years found that dyslipidemia with low HDL-C levels was associated with excessive daytime sleepiness regardless of age, sex, and BMI $z$ score. ${ }^{68)}$

The discrepancies in the results of previous studies in relation to specific lipid profiles are due to the characteristics of psychiatric diseases being affected by environmental factors, while their prevalence is dependent on age and sex. Since lipid profiles are affected by age and sex as well as dietary intake, further studies investigating the relationship between cholesterol factors and mental and behavioral health issues should be designed to control for confounders such as socioeconomic status, age, and sex.

\section{Conclusions}

This article reviewed dyslipidemia-related pediatric health issues. The reviewed pediatric studies are summarized in Tables 2-4. Pediatric dyslipidemia might be associated with low serum vitamin D levels, asthma, and mental health problems such as depression and suicidality despite conflicting results for specific lipid profiles. This review provides important evidence that can increase our understanding of the impact of childhood lipid profiles. However, the studies reviewed were primarily based on association studies that do not prove cause and effect. Therefore, further large-scale population-based interventional studies are needed to establish effective screening and treatment guidelines for dyslipidemia and preventive strategies for related health problems among Korean children and adolescents.

\section{Footnote}

Conflicts of interest: No potential conflict of interest relevant to

Table 3. Summary of studies on respiratory diseases related to childhood dyslipidemia

\begin{tabular}{|c|c|c|c|c|c|}
\hline Health problems & Study & Study design & $\begin{array}{l}\text { Subjects } \\
\text { number }\end{array}$ & Subjects characteristics & Results \\
\hline $\begin{array}{l}\text { Physician-diagnosed } \\
\text { asthma }\end{array}$ & Cottrell et al., ${ }^{45)} 2011$ & Cross-sectional $^{\mathrm{a})}$ & 17,994 & $\begin{array}{l}\text { Americans ( } 91 \% \text { Caucasian) } \\
\text { aged 4-12 years }\end{array}$ & Association with high TG levels \\
\hline $\begin{array}{l}\text { Physician-diagnosed } \\
\text { asthma }\end{array}$ & Park et al., ${ }^{51)} 2017$ & Cross-sectional & 644 & Koreans, aged $15-16$ years & Association with high HDL in males \\
\hline Self-reported asthma & Ko et al., ${ }^{50)} 2018$ & (ross-sectionala $^{\mathrm{a})}$ & 2,841 & Koreans aged $11-18$ years & $\begin{array}{l}\text { Association with high TC and TG/ } \\
\text { HDL-C levels }\end{array}$ \\
\hline Self-reported asthma & Lu et al., ${ }^{52)} 2019$ & Cross-sectionala $^{\text {a) }}$ & 23,841 & $\begin{array}{l}\text { Americans ( } 59 \% \text { Caucasian) } \\
\text { aged 3-19 years }\end{array}$ & $\begin{array}{l}\text { No association with low HDL-C and } \\
\text { high TC, LDL-C, and TG levels }\end{array}$ \\
\hline $\begin{array}{l}\text { Physician-diagnosed } \\
\text { asthma }\end{array}$ & $\begin{array}{l}\text { Mensink-Bout et al., } \\
2021\end{array}$ & Prospective cohort ${ }^{\mathrm{a})}$ & 4,988 & $\begin{array}{l}\text { European } 68 \% \text {, at the age of } \\
6 \text { and } 10 \text { years }\end{array}$ & $\begin{array}{l}\text { No association with } T C, H D L-C \text {, and TG } \\
\text { levels }\end{array}$ \\
\hline Asthma & $\begin{array}{l}\text { Peng and Huang }{ }^{49)} \\
2017\end{array}$ & Meta- analysis & $\begin{array}{l}891 \text { Cases, } \\
5,530 \text { controls }\end{array}$ & $\begin{array}{l}2 \text { Prospective and } 3 \text { cross- } \\
\text { sectional pediatric studies }\end{array}$ & $\begin{array}{l}\text { Association with low HDL-C levels } \\
\text { No association with LDL-C levels }\end{array}$ \\
\hline Asthma & Su et al., ${ }^{47)} 2018$ & Meta- analysis & 32,604 & $\begin{array}{l}\text { Including } 9 \text { pediatric studies } \\
\text { out of } 20 \text { studies }\end{array}$ & $\begin{array}{l}\text { Association with high TC and LDL-C } \\
\text { levels } \\
\text { No association with TG and HDL-C } \\
\text { levels }\end{array}$ \\
\hline
\end{tabular}

TG, triglyceride; HDL, high-density lipoprotein; TC, total cholesterol; HDL-C, HDL-cholesterol; LDL-C, low-density lipoprotein cholesterol.

a) The results were analyzed after adjusting for body fatness/body mass index and/or sex.

Table 4. Summary of studies on mental and behavioral health problems related to childhood dyslipidemia

\begin{tabular}{|c|c|c|c|c|c|}
\hline Health problems & Study & Study design & $\begin{array}{l}\text { Subjects } \\
\text { number }\end{array}$ & Subjects characteristics & Results \\
\hline Suicidal tendencies & Apter et al., ${ }^{64)} 1999$ & Cross-sectional & 152 & $\begin{array}{l}\text { Jews psychiatric inpatients } \\
\text { aged } 12-21 \text { years }\end{array}$ & Association with high TC levels \\
\hline Suicide attempt & Plana et al., ${ }^{65)} 2010$ & Case-control & $\begin{array}{l}66 \text { Cases } \\
54 \text { Controls }\end{array}$ & Hispanics aged 8-18 years & Association with low TC levels \\
\hline $\begin{array}{l}\text { Self-reported } \\
\text { depressive mood }\end{array}$ & Kim et al., ${ }^{66)} 2019$ & Cross-sectionala $^{\mathrm{a})}$ & 2,454 & Koreans aged $12-18$ years & $\begin{array}{l}\text { Association with high LDL-C levels in } \\
\text { boys }\end{array}$ \\
\hline $\begin{array}{l}\text { Self-reported } \\
\text { depressive } \\
\text { symptoms }\end{array}$ & Park et al., ${ }^{67)} 2020$ & Prospective cohort ${ }^{\mathrm{a})}$ & 1,071 & Koreans aged $15-16$ years & $\begin{array}{l}\text { Association with consistently low or } \\
\text { increased TC levels during adole- } \\
\text { scence in boys }\end{array}$ \\
\hline $\begin{array}{l}\text { Daytime excessive } \\
\text { sleepiness }\end{array}$ & Sung et al., ${ }^{68)} 2021$ & Cross-sectional $^{\mathrm{a})}$ & 618 & Korean aged $10-12$ years & Association with low HDL-C levels \\
\hline
\end{tabular}

TC, total cholesterol; LDL-C, low-density lipoprotein cholesterol; HDL-C, high-density lipoprotein cholesterol.

${ }^{\text {a) } T h e ~ r e s u l t s ~ w e r e ~ a n a l y z e d ~ a f t e r ~ a d j u s t i n g ~ f o r ~ h o u s e h o l d ~ i n c o m e, ~ d i e t a r y ~ i n t a k e, ~ b o d y ~ f a t n e s s / b o d y ~ m a s s ~ i n d e x, ~ a n d / o r ~ s e x . ~}$ 


\section{References}

1. McGill HC Jr, McMahan CA, Zieske AW, Malcom GT, Tracy RE, Strong JP. Effects of nonlipid risk factors on atherosclerosis in youth with a favorable lipoprotein profile. Circulation 2001;103:1546-50.

2. Kavey RE, Daniels SR, Lauer RM, Atkins DL, Hayman LL, Taubert K. American Heart Association guidelines for primary prevention of atherosclerotic cardiovascular disease beginning in childhood. Circulation 2003;107:1562-66.

3. Expert Panel on Integrated Guidelines for Cardiovascular Health and Risk Reduction in Children and Adolescents. Expert panel on integrated guidelines for cardiovascular health and risk reduction in children and adolescents: summary report. Pediatrics 2011;128 Suppl 5:S213-56.

4. Grundy SM, Stone NJ, Bailey AL, Beam C, Birtcher KK, Blumenthal RS, et al. 2018 AHA/ACC/AACVPR/AAPA/ABC/ACPM/ADA/AGS/ APhA/ASPC/NLA/PCNA Guideline on the management of blood choleterol: a report of the American College of Cardiology/American Heart Association task force on clinical practice guidelines. Circulation 2019;139:e1082-143.

5. de Ferranti SD, Steinberger J, Ameduri R, Baker A, Gooding H, Kelly AS, et al. Cardiovascular risk reduction in high-risk pediatric patients: a scientific statement from the American Heart Association. Circulation 2019;139:e603-34.

6. Christensen B, Glueck C, Kwiterovich P, Degroot I, Chase G, Heiss G, et al. Plasma cholesterol and triglyceride distributions in 13,665 children and adolescents: The Prevalence Study of the Lipid Research Clinics Program. Pediatr Res 1980;14:194-202.

7. NCEP Expert Panel on Blood Cholesterol Levels in Children and Adolescents. National Cholesterol Education Program (NCEP): highlights of the report of the Expert Panel on Blood Cholesterol Levels in Children and Adolescents. Pediatrics 1992;89:495-501.

8. Lim JS, Kim EY, Kim JH, Yoo JH, Yi KH, Chae HW, et al. 2017 Clinical practice guidelines for dyslipidemia of Korean children and adolescents. Clin Exp Pediatr 2020;63:454-62.

9. Yang S, Hwang JS, Park HK, Lee HS, Kim HS, Kim EY, et al. Serum lipid concentrations, prevalence of dyslipidemia, and percentage eligible for pharmacological treatment of Korean children and adolescents; data from the Korea National Health and Nutrition Examination Survey IV (2007-2009). PLoS One 2012; 7:e49253.

10. Shim YS, Baek JW, Kang MJ, Oh YJ, Yang S, Hwang IT. Reference values for the triglyceride to high-density lipoprotein cholesterol ratio and nonhigh-density lipoprotein cholesterol in Korean children and adolescents: The Korean National Health and Nutrition Examination Surveys 20072013. J Atheroscler Thromb 2016;23:1334-44.

11. Ministry of Health and Welfare, Korea Centers for Disease Control and Prevention. 2019 National Health Statistics, 8th National Health and Nutrition Examination Survey: First Year (2019). Cheongju (Korea): Korea Centers for Disease Control and Prevention, 2020.

12. Lim JS. The current state of dyslipidemia in Korean children and adolescents and its management in clinical practice. Ann Pediatr Endocrinol Metab 2013;18:1-8.

13. Yoon JM. Dyslipidemia in children and adolescents: when and how to diagnose and treat? Pediatr Gastroenterol Hepatol Nutr 2014;17:85-92.

14. Rhee EJ, Kim HC, Kim JH, Lee EY, Kim BJ, Kim EM, et al. 2018 Guidelines for the management of dyslipidemia. Korean J Intern Med 2019;34:723-71.

15. Kliegman RM, St Geme III JW, Blum NJ, Shah SS, Tasker RC, Wilson KM. Nelson textbook of pediatrics. 21st ed. Philadelphia (PA): Elsevier Health Sciences, 2020.

16. Li YC, Kong J, Wei M, Chen ZF, Liu SQ, Cao LP. 1,25-Dihydroxyvitamin $\mathrm{D}(3)$ is a negative endocrine regulator of the renin-angiotensin system. J Clin Invest 2002;110:229-38.

17. Delvin E, Souberbielle JC, Viard JP, Salle B. Role of vitamin D in acquired
18. Christensen R, Lorenzen JK, Svith CR, Bartels EM, Melanson EL, Saris $\mathrm{WH}$, et al. Effect of calcium from dairy and dietary supplements on faecal fat excretion: a meta-analysis of randomized controlled trials. Obes Rev 2009;10:475-86.

19. Cho HJ, Kang HC, Choi SA, Ju YC, Lee HS, Park HJ. The possible role of $\mathrm{Ca} 2+$ on the activation of microsomal triglyceride transfer protein in rat hepatocytes. Biol Pharm Bull 2005;28:1418-23.

20. Vaskonen T, Mervaala E, Sumuvuori V, Seppanen-Laakso T, Karppanen $\mathrm{H}$. Effects of calcium and plant sterols on serum lipids in obese Zucker rats on a low-fat diet. Br J Nutr 2002;87:239-45.

21. Lacour B, Basile C, Drueke T, Funck-Brentano JL. Parathyroid function and lipid metabolism in the rat. Miner Electrolyte Metab 1982;7:157-65.

22. Chiu KC, Chu A, Go VL, Saad MF. Hypovitaminosis D is associated with insulin resistance and beta cell dysfunction. Am J Clin Nutr 2004;79:8205.

23. Pittas AG, Chung M, Trikalinos T, Mitri J, Brendel M, Patel K, et al. Systematic review: vitamin D and cardiometabolic outcomes. Ann Intern Med 2010;152:307-14.

24. Burgaz A, Orsini N, Larsson SC, Wolk A. Blood 25-hydroxyvitamin D concentration and hypertension: a meta-analysis. J Hypertens 2011; 29:636-45.

25. Jiang X, Peng M, Chen S, Wu S, Zhang W. Vitamin D deficiency is associated with dyslipidemia: a cross-sectional study in 3788 subjects. Curr Med Res Opin 2019;35:1059-63.

26. Kelishadi R, Farajzadegan Z, Bahreynian M. Association between vitamin $D$ status and lipid profile in children and adolescents: a systematic review and meta-analysis. Int J Food Sci Nutr 2014;65:404-10.

27. Ha CD, Cho JK, Lee SH, Kang HS. Serum vitamin D, physical activity, and metabolic risk factors in Korean children. Med Sci Sports Exerc 2013;45:102-8.

28. Lee SH, Kim SM, Park HS, Choi KM, Cho GJ, Ko BJ, et al. Serum 25-hydroxyvitamin D levels, obesity and the metabolic syndrome among Korean children. Nutr Metab Cardiovasc Dis 2013;23:785-91.

29. Nam GE, Kim DH, Cho KH, Park YG, Han KD, Kim SM, et al. 25-Hydroxyvitamin D insufficiency is associated with cardiometabolic risk in Korean adolescents: the 2008-2009 Korea National Health and Nutrition Examination Survey (KNHANES). Public Health Nutr 2014;17:186-94.

30. Kim MR, Jeong SJ. Relationship between vitamin D level and lipid profile in non-obese children. Metabolites 2019;9:125.

31. Song K, Park G, Choi Y, Oh JS, Choi HS, Suh J, et al. Association of vitamin D status and physical activity with lipid profile in Korean children and adolescents: a population-based study. Children (Basel) 2020;7:241.

32. Ponda MP, Huang X, Odeh MA, Breslow JL, Kaufman HW. Vitamin D may not improve lipid levels. Circulation 2012;126:270-7.

33. Challoumas D. Vitamin D supplementation and lipid profile: what does the best available evidence show? Atherosclerosis 2014;235:130-9.

34. Tavakoli F, Namakin K, Zardast M. Vitamin D supplementation and highdensity lipoprotein cholesterol: a study in healthy school children. Iran J Pediatr 2016;26:e3311.

35. Khayyatzadeh SS, Mirmoosavi SJ, Fazeli M, Abasalti Z, Avan A, Javandoost A, et al. High-dose vitamin D supplementation is associated with an improvement in several cardio-metabolic risk factors in adolescent girls: a nine-week follow-up study. Ann Clin Biochem 2018;55:227-35.

36. Yarparvar A, Elmadfa I, Djazayery A, Abdollahi Z, Salehi F, Heshmat R. The effects of vitamin D supplementation on lipid and inflammatory profile of healthy adolescent boys: a randomized controlled trial. Nutrients 2020;12:1213.

37. Hauger H, Laursen RP, Ritz C, Mølgaard C, Lind MV, Damsgaard CT. Effects of vitamin D supplementation on cardiometabolic outcomes in children and adolescents: a systematic review and meta-analysis of randomized controlled trials. Eur J Nutr 2020;59:873-84.

38. Baumruker T, Csonga R, Pursch E, Pfeffer A, Urtz N, Sutton S, et al. Activation of mast cells by incorporation of cholesterol into rafts. Int Immunol 2003;15:1207-18. 
39. Delvecchio CJ, Bilan P,Nair P, Capone JP.LXR-induced reverse cholesterol transport in human airway smooth muscle is mediated exclusively by ABCA1. Am J Physiol Lung Cell Mol Physiol 2008;295:L949-57.

40. Shore SA. Obesity and asthma: possible mechanisms. J Allergy Clin Immunol 2008;121:1087-93.

41. Azizpour Y, Delpisheh A, Montazeri Z, Sayehmiri K, Darabi B. Effect of childhood BMI on asthma: a systematic review and meta-analysis of casecontrol studies. BMC Pediatr 2018;18:143.

42. Deng X, Ma J, Yuan Y, Zhang Z, Niu W. Association between overweight or obesity and the risk for childhood asthma and wheeze: an updated meta-analysis on 18 articles and 73252 children. Pediatr Obes 2019;14: e12532.

43. Perez MK, Piedimonte G. Metabolic asthma: is there a link between obesity, diabetes, and asthma? Immunol Allergy Clin North Am 2014;34: 777-84.

44. Goran M, Ball G, Cruz M. Obesity and risk of type 2 diabetes and cardiovascular disease in children and adolescents. J Clin Endocrinol Metab 2003;88:1417-27.

45. Cottrell L, Neal WA, Ice C, Perez MK, Piedimonte G. Metabolic abnormalities in children with asthma. Am J Respir Crit Care Med 2011; 183:441-8.

46. Fenger RV, Gonzalez-Quintela A, Linneberg A, Husemoen LLN, Thuesen $\mathrm{BH}$, Aadahl M, et al. The relationship of serum triglycerides, serum HDL, and obesity to the risk of wheezing in 85,555 adults. Respir Med 2013;107:816-24.

47. Su X, Ren Y, Li M, Zhao X, Kong L, Kang J. Association between lipid profile and the prevalence of asthma: a meta-analysis and systemic review. Curr Med Res Opin 2018;34:423-33.

48. Trakaki A, Marsche G. High-density lipoprotein (HDL) in allergy and skin diseases: focus on immunomodulating functions. Biomedicines 2020;8:558.

49. Peng J, Huang Y. Meta-analysis of the association between asthma and serum levels of high-density lipoprotein cholesterol and low-density lipoprotein cholesterol. Ann Allergy Asthma Immunol 2017;118:61-5.

50. Ko SH, Jeong J, Baeg MK, Han KD, Kim HS, Yoon JS, et al. Lipid profiles in adolescents with and without asthma: Korea National Health and Nutrition Examination Survey data. Lipids Health Dis 2018;17:158.

51. Park JH, Mun S, Choi DP, Lee JY, Kim HC. Association between high-density lipoprotein cholesterol level and pulmonary function in healthy Korean adolescents: the JS high school study. BMC Pulm Med 2017;17:190

52. Lu M, Wu B, Qiao R, Gu H, Din Y, Dong X. No associations between serum lipid levels or HOMA-IR and asthma in children and adolescents: a NHANES analysis. J Clin Res Pediatr Endocrinol 2019;11:270-7.

53. Mensink-Bout SM, Santos S, de Jongste JC, Jaddoe VWV, Duijts L. Cardio-metabolic risk factors during childhood in relation to lung function and asthma. Pediatr Allergy Immunol 2021;32:945-52.

54. Boston PF, Dursun SM, Reveley MA. Cholesterol and mental disorder. Br J Psychiatry 1996;169:682-9.

55. Werner HB, Krämer-Albers EM, Strenzke N, Saher G, Tenzer S, Ohno-
Iwashita Y, et al. A critical role for the cholesterol-associated proteolipids PLP and M6B in myelination of the central nervous system. Glia 2013;61:567-86.

56. Vevera J, Fišar Z, Kvasnička T, Zdenek H, Stárková L, Češka R, et al. Cholesterol-lowering therapy evokes time-limited changes in serotonergic transmission. Psychiatry Res 2005;133:197-203.

57. Engelberg H. Low serum cholesterol and suicide. Lancet 1992;339:7279.

58. Beasley CL, Honer WG, von Bergmann K, Falkai P, Lütjohann D, Bayer TA. Reductions in cholesterol and synaptic markers in association cortex in mood disorders. Bipolar Disord 2005;7:449-55.

59. Wu S, Ding Y, Wu F, Xie G, Hou J, Mao P. Serum lipid levels and suicidality: a meta-analysis of 65 epidemiological studies. J Psychiatry Neurosci 2016;41:56-69.

60. Persons JE, Fiedorowicz JG. Depression and serum low-density lipoprotein: a systematic review and meta-analysis. J Affect Disord 2016;206:5567.

61. Wei YG, Cai DB, Liu J, Liu RX, Wang SB, Tang YQ, et al. Cholesterol and triglyceride levels in first-episode patients with major depressive disorder: a meta-analysis of case-control studies. J Affect Disord 2020;266:465-72.

62. Oh J, Kim TS. Serum lipid levels in depression and suicidality: the Korea National Health and Nutrition Examination Survey (KNHANES) 2014. J Affect Disord 2017;213:51-8.

63. Shin HY, Kang G, Kang HJ, Kim SW, Shin IS, Yoon JS, et al. Associations between serum lipid levels and suicidal ideation among Korean older people. J Affect Disord 2016;189:192-8.

64. Apter A, Laufer N, Bar-Sever M, Har-Even D, Ofek H, Weizman A. Serum cholesterol, suicidal tendencies, impulsivity, aggression, and depression in adolescent psychiatric inpatients. Biol Psychiatry 1999;46:532-41.

65. Plana T, Gracia R, Méndez I, Pintor L, Lazaro L, Castro-Fornieles J. Total serum cholesterol levels and suicide attempts in child and adolescent psychiatric inpatients. Eur Child Adolesc Psychiatry 2010;19:615-9.

66. Kim EJ, Hong J, Hwang JW. The association between depressive mood and cholesterol levels in Korean adolescents. Psychiatry Investig 2019; 16:737-44

67. Park JH, Jung SJ, Jung Y, Ahn SV, Lee E, Kim HC. Association between the change of total cholesterol during adolescence and depressive symptoms in early adulthood. Eur Child Adolesc Psychiatry 2020;30:261-9.

68. Sung M, Rhie S, Kim JH, Lee SW, Ha EK, Jee HM, et al. Assessment of vitamin $\mathrm{D}$, exercise, and lipid profile associated with excessive daytime sleepiness in school children. Sleep Med 2021;77:51-7.

How to cite this article: Hong J. A new perspective on cholesterol in pediatric health: association of vitamin D metabolism, respiratory diseases, and mental health problems. Clin Exp Pediatr 2022;65:65-72. https://doi.org/10.3345/cep. 2020.00934 